\title{
PERANAN LAPORAN KEUANGAN DALAM RANGKA MEMBERDAYAKAN DAN MENGEMBANGKAN USAHA MIKRO KECIL DAN MENENGAH DI KABUPATEN SUKOHARJO
}

\author{
Djoko Sigit Gunanto \\ STIE AAS Surakarta \\ Email:djoko.sigitg@gmail.com
}

\begin{abstract}
ABSTRAK
This study aims to determine the accounting practices in the financial statements of Micro, Small and Medium Enterprises in Sukoharjo, as well as to determine the barriers that exist in the application of accounting financial statements in Micro, Small and Medium Enterprises and how to overcome these obstacles. While the method of this study used a qualitative approach with descriptive qualitative oriented. Data and information obtained from the UMKM in Sukoharjo and other secondary data sources.

The results showed that the First, the application of existing financial statements in Sukoharjo still not up, a lot of UMKM only use simple remarks did not even make financial records at all, resulting in low utilization of accounting information in the development of UMKM. Second, barriers experienced by UMKM in applying the financial statements are ignorance about the benefits of the financial statements for business development, a lack of knowledge of the perpetrators of Micro, Small and Medium Enterprises in making financial reports, UMKM have not felt directly from the application of accounting financial statements. The fix takes the role of government and relevant parties to help UMKM implement the financial statements to empower their business.
\end{abstract}

Keywords: Accounting, Financial Statements, UMKM

\section{PENDAHULUAN}

\section{Latar Belakang}

Perkembangan Usaha Mikro Kecil Menengah atau sering disingkat (UMKM) di Indonesia cukup besar.Menurut data dari Kementrian Koprasi dan Usaha Mikro Kecil Menengah, hingga tahun 2012, jumlah unit usaha secara keseluruhan sebanyak 56.539.560 unit usaha, dengan jumlah usaha terbanyak adalah usaha mikro sebanyak 55.856.176 unit usaha $(98,79 \%)$, diikuti oleh usaha kecil sebanyak 629.418 unit usaha $(1,10 \%)$, usaha menengah sebanyak 48.997 unit usaha
$(0,09 \%)$, dan usaha besar sebanyak 4.968 unit usaha $(0,01 \%)$. Dalam hal mengatasi masalah pengangguran sampai dengan tahun 2012 terdapat 107.657.509 tenaga kerja yang terserap UMK

Sementara itu, Bupati Sukoharjo, Wardoyo Wijaya menyatakan, jumlah UMKM di Kota Makmur sebanyak 28.618 lokasi. Terdiri atas kluster- kluster seperti kluster rotan di Kecamatan Gatak, kluster gamelan di Wirun, Kecamatan Mojolaban, kluster jamu di Kecamatan Nguter dan sebagainya. Usaha Mikro Kecil Menengah (UMKM) merupakan salah satu penggerak perekonomian bangsa. UMKM diharapkan dapat 
meningkatan daya saing bangsa, pertumbuhan ekonomi, pengurangan kemiskinan, dan peningkatan standar hidup penduduk Indonesia. UMKM harus dapat bersaing dan mampu menangkap setiap kesempatan yang ada agar tetap dapat berkiprah dalam perekonomian bangsa ini.

Perkembangan jumlah UMKM dari tahun ke tahun semakin bertambah. Namun perkembangan UMKM baru terlihat dari sisi jumlahnya saja. Dalam aspek financial, hanya sedikit UMKM yang mengalami perkembangan dalam hal ini kinerja keuangannya. Hal ini tak lepas dari kesadaran pelaku UMKM terhadap pentingnya pengelolaan keuangan perusahaan. Adapun kegiatan penyusunan laporan keuangan, masih dianggap mewah dan belum sebanding dengan kegunaannya. Akibatnya pelaku UKM tidak mengetahui secara persis berapa pendapatan (kas) yang seharusnya diterima, berapa biaya operasi yang seharusnya dikeluarkan dan berapa yang seharusnya masih tersisa. Kalaupun ada perencanaan kegiatan, biasanya tidak tersusun secara tertib sehingga mengalami kesulitan bagaimana cara mengalokasikan dana (kas) yang ada sekarang. Permasalahan itu semakin kompleks seiring dengan semakin besarnya kegiatan usaha UKM.

Dengan semakin luasnya ukuran usaha, pelaku UKM menjadi tidak mampu lagi memantau secara langsung kegiatan usaha yang sedang berjalan. Masalah tersebut dapat diatasi dengan membuat laporan keuangan dan menganalisisnya lebih lanjut. Selain itu tidak sedikit pelaku UMKM yang tidak memisahkan keuangan pribadi dengan keuangan usaha, sehingga sering kali uang yang seharusnya untuk kepentingan usaha digunakan untuk keperluan pribadi. Akibatnya usaha tersebut akan kekurangan modal dan akan sulit berkembang dan bahkan mungkin bangkrut karena tidak dapat membiayai kegiatan operasionalnya.

Setiap usaha diharapkan mempunyai laporan keuangan untuk menganalisis kinerja keuangan sehingga dapat memberikan informasi tentang posisi keuangan, kinerja dan arus kas perusahaan yang bermanfaat bagi pengguna laporan keuangan dalam rangka membuat keputusan-keputusan ekonomi. Namun praktek akuntansi keuangan pada Usaha Mikro Kecil Menengah masih rendah dan memiliki banyak kelemahan.

\section{Tujuan Penelitian}

Penelitian ini bertujuan untuk mengetahui praktik akuntansi laporan keuangan di Usaha Mikro Kecil dan Menengah di Kabupaten Sukoharjo, serta untuk mengetahui hambatanhambatan yang ada dalam penerapan akuntansi laporan keuangan di Usaha Mikro Kecil Menengah tersebut dan cara mengatasi hambatan tersebut.

\section{KAJIAN PUSTAKA}

\section{Akuntansi}

Akuntansi adalah seni dalam mengukur, berkomunikasi dan menginterpretasikan aktivitas keuangan. Secara luas, akuntansi juga dikenal sebagai "bahasa bisnis".Akuntansi adalah pengukuran, penjabaran, atau pemberian kepastian mengenai informasi yang akan membantu manajer, investor, otoritas pajak dan pembuat keputusan lain untuk membuat alokasi sumber daya keputusan di dalam perusahaan, organisasi, dan lembaga pemerintah. Menurut Kieso akuntansi adalah pengindentifikasian, pengukuran, dan pengkomunikasian informasi keuangan tentang entitas ekonomi kepada pemakai yang berkepentingan. Menurut Warren 
dkk akuntansi adalah sistem informasi yang menghasilkan laporan kepada pihak-pihak yang berkepentingan mengenai aktivitas ekonomi dan kondisi perusahaan.

Akuntansi bertujuan untuk menyiapkan suatu laporan keuangan yang akurat agar dapat dimanfaatkan oleh para manajer, pengambil kebijakan, dan pihak berkepentingan lainnya, seperti pemegang saham, kreditur, atau pemilik. Pencatatan harian yang terlibat dalam proses ini dikenal dengan istilah pembukuan. Akuntansi keuangan adalah suatu cabang dari akuntansi dimana informasi keuangan pada suatu bisnis dicatat, diklasifikasi, diringkas, diinterpretasikan, dan dikomunikasikan. Auditing, satu disiplin ilmu yang terkait tapi tetap terpisah dari akuntansi, adalah suatu proses dimana pemeriksa independen memeriksa laporan keuangan suatu organisasi untuk memberikan suatu pendapat atau opini yang masuk akal tapi tak dijamin sepenuhnya mengenai kewajaran dan kesesuaiannya dengan prinsip akuntansi yang berterima umum. Menurut Littleto tujuan utama dari akuntansi adalah untuk melaksanakan perhitungan periodik antara biaya (usaha) dan hasil (prestasi). Konsep ini merupakan inti dari teori akuntansi dan merupakan ukuran yang dijadikan sebagai rujukan dalam mempelajari akuntansi.

\section{Laporan Keuangan}

Pengertian laporan keuangan menurut PSAK No1 (2004) merupakan bagian dari proses pelaporan keuangan yg lengkap dari laporan laba rugi neraca laporan arus kas laporan perubahan posisi keuangan (yang dapat disajikan dalam berbagai cara misal sebagai laporan arus kas atau laporan arus dana) catatan dan laporan serta materi penjelasan yg merupakan bagian intergral dalam laporan keuangan.
Menurut Munawir dalam bukunya Analisa Laporan Keuangan menyatakan bahwa laporan keuangan adalah bersifat historis dan menyeluruh sebagai suatu laporan kemajuan (progress report).Selain itu, dikatakan bahwa laporan keuangan terdiri dari data-data yang merupakan hasil dari suatu kombinasi antara fakta-fakta yang telah dicatat (recorded fact), prinsip- prinsip, dan kebiasaan-kebiasaan di dalam akuntansi (accountung convention and postulate), serta pendapat pribadi (personal judgement).

Zaki Baridwan menyatakan bahwa laporan keuangan adalah merupakan ringkasan dari suatu proses pencatatan, merupakan suatu ringkasan, dan transaksi-transaksi keuangan yang terjadi selama satu tahun buku yang bersangkutan. Kemudian, pengertian di dalam standar akuntansi keuangan, Laporan keuangan adalah merupakan bagian dari proses pelaporan keuangan dan laporan keuangan lengkap biasanya meliputi neraca, laporan laba rugi, laporan perubahan posisi keuangan (yang dapat disajikan dalam berbagai cara, seperti sebagai laporan arus kas), catatan, laporan keuangan lain, dan materi penjelasan yang bagian integral dari laporan keuangan. Laporan keuangan dapat dipakai sebagai alat berkomunikasi dengan pihak-pihak berkepentingan dengan data keuangan perusahaan, dan karena itulah sering juga disebut sebagai language of business.

\section{Fungsi dan Tujuan Laporan Keuangan}

Dalam membuat laporan keuangan tentunya seseorang harus mengetahui fungsi dan juga menetapkan tujuan dari pembuatan laporan keuangan tersebut. Secara umum fungsi dan tujuan dari disusunnya suatu laporan keuangan adalah untuk menyediakan suatu informasi 
yang menyangkut posisi keuangan, kinerja perusahaan, serta perubahan posisi keuangan suatu perusahaan yang bermanfaat bagi yang berkepentingan untuk mengambil keputusan strategis.

PSAK, (2004) mengungkapkan tentang tujuan umum laporan keuangan. Tujuan tersebut adalah menyediakan informasi yg menyangkut posisi keuangan suatu perusahaan yg bermanfaat bagi sejumlah besar pemakai dalam pengambilan keputusan ekonomi serta menunjukkan kinerja yg telah dilakukan manajemen (stewardship) atau pertanggungjawaban manajemen atas penggunaan sumber-sumber daya yg dipercayakan kepadanya.

Menurut Standar Akuntansi Keuangan, 2009. Pemakai laporan keuangan meliputi: investor, karyawan, pemberian pinjaman, pemasok dan kreditur usaha lain, pelanggan, pemerintah, dan masyarakat.

\section{UMKM}

UMKM adalah singkatan dari usaha Mikro, Kecil dan Menengah.UMKM diatur berdasarkan UU Nomor 20 tahun 2008 tentang Usaha Mikro, Kecil dan Menengah.Berikut kutipan dari isi UU 20/2008.
1. Usaha Mikro adalah usaha produktif milik orang perseorangan dan/atau badan usaha perorangan yang memenuhi criteria Usaha Mikro sebagai diatur dalam Undang-Undang ini.

2. Usaha Kecil adalah usaha ekonomi produktif yag berdiri sendiri, yang dilakukan oleh orang perorangan atau badan usaha yang bukan merupakan anak perusahaan atau bukan cabang perusahaan yag dimiliki, dikuasai, atau menjadi bagian baik langsung maupun tidak langsung dari usaha menengah atau usaha besar yang memenuhi kriteria Usaha Kecil sebagaimana dimaksud dalam Undang-Undang ini.

3. Usaha Menengah adalah usaha ekonomi produktif yang berdiri sendiri, yang dilakukan oleh orang perseorangan atau badan usaha yang bukan merupakan anak perusahaan atau cabang perusahaan yang dimiliki, dikuasai, atau menjadi bagian baik langsung maupun tidak langsung dengan Usaha Kecil atau usaha besar dengan jumlah kekayaan bersih atau hasil penjualan tahunan sebagaimana diatur dalam Undang-Undang ini.

\section{Tabel 1}

Kriteria UMKM

\begin{tabular}{|r|c|c|c|}
\hline \multirow{2}{*}{ No } & \multirow{2}{*}{ Uraian } & Ksset & Omset \\
\cline { 3 - 4 } & & Maks. 50 Juta & Maks. 300 Juta \\
\hline 1. & Usaha Mikro & $>50$ Juta -500 juta & $>300$ Juta $-2,5$ Miliar \\
\hline 2. & Usaha Kecil & $>500$ Juta -10 Miliar & $>2,5$ Miliar -50 Miliar \\
\hline 3 & Usaha Menengah & $>$ &
\end{tabular}




\section{Perkembangan UMKM di Indonesia}

Usaha kecil dan menengah (UKM) di berbagai negara termasuk di Indonesia merupakan salah satu penggerak perekonomian rakyat yang tangguh. Hal ini karena kebanyakan para pengusaha kecil dan menengah berangkat dari industri keluarga/ rumahan. Dengan demikian konsumennya pun berasal dari kalangan menengah ke bawah. Selain itu peranan UMKM terutama sejak krisis moneter tahun 1998 dapat dipandang sebagai penyelamat dalam proses pemulihan ekonomi nasional, baik dalam mendorong laju pertumbuhan ekonomi maupun penyerapan tenaga kerja.

Pada tahun 2012, terjadi perkembangan terhadap jumlah UMKM di Indonesia. Jumlah UMKM, diprediksi telah mencapai 6.534.592 unit, yaitu terdiri dari Usaha Mikro sebanyak 55.856.176 unit, Usaha Kecil sebanyak 629.418 unit dan Usaha Menengah 48.997 unit. Jumlah UMKM ini meningkat sebesar 2,41 persen dari tahun sebelumnya. Perkembangan jumlah UMKM dan Koperasi tersebut berdampak pada peningkatan penyerapan tenaga kerja di kedua sektor tersebut. Pada tahun 2012, diprediksikan jumlah penyerapan tenaga kerja UMKM sebanyak 107.657.509 orang atau meningkat 5,83 persen dari jumlah tenaga kerja pada tahun 2011 yaitu sebesar 101.722.458 orang.

Berdasarkan data-data tersebut maka disimpulkan bahwa jumlah UMKM di Indonesia setiap tahunnya mengalami peningkatan yang signifikan, hal ini juga berdampak pada semakin meningkatnya kontribusi UMKM terhadap perekonomian bangsa. Oleh karenanya, sudah sepantasnya seluruh pihak baik pemerintah, pemerintah daerah, dunia usaha (BUMN \& Usaha Besar) dan masyarakat memberikan perhatian bagi pengembangan dan pemberdayaan UMKM di Indonesia, termasuk mengupayakan peningkatan kemampuan dalam pengelolaan usaha dan keuangan, agar UMKM dapat mandiri, produktif dan memiliki daya saing tinggi dengan usaha-usaha lian di luar UMKM.

\section{METODE PENELITIAN}

Penelitian ini menggunakan pendekatan kualitatif dengan berorientasi pada deskriftif kualitatif. Pendekatan ini dipilih karena dalam penelitian ini mengarah pada pendiskripsian secara rinci dan mendalam mengenai gambaran kondisi yang sebenarnya terjadi di lapangan.

\section{Metode Pengumpulan Data}

1. Observasi

Metode pengumpulan data dalam penelitian dengan cara mengadakan pengamatan langsung terhadap kegiatankegiatan yang ada di lingkungan Usaha Mikro Kecil dan Menengah Kabupaten Sukoharjo.

2. Interview

Metode pengumpulan data penelitian, dimana peneliti melakukan wawancara dengan pelaku UMKM di Kabupaten Sukoharjo maupun pihak-pihak yang berkompenten yang terkait penelitian.

3. Studi pustaka

Metode pengumpulan data penelitian yang dilakukan dengan cara memperoleh datanya melalui membaca buku-buku, dokumen-dokumen dan lain sebagainya yang ada hubungannya dengan materi yang diketengahkan oleh penulis. 
Sumber Data

1. Data Primer

Data primer adalah data yang diperoleh langsung dari para pelaku UMKM, terutama hasil observasi secara langsung dan wawancara dengan pelaku UMKM. Selain itu peneliti juga mewawancarai beberapa tokoh yang kompeten dibidang laporan keuangan.

2. Data Sekunder

Data sekunder merupakan data pendukung atau data penguat yang didapat dari sumber-sumber lain, yaitu tulisan, artikel atau makalah kepustakaan yang berkaitan dengan pengelolaan UMKM..

\section{PEMBAHASAN DAN HASIL PENELITIAN}

\section{A. Gambaran Umum Kabupaten Sukoharjo UMKMnya}

1. Sejarah Kabupaten Sukoharjo

Pada masa pendudukan Jepang, wilayah Karesidenan Surakarta pernah merupakan Daerah Istimewa yang dikenal dengan Solo Ko (Kasunanan) dan Mangkunegaran Ko (Mangkunegaran). Wilayah Mangkunegaran meliputi daerah Kabupaten Karanganyar, Wonogiri, dan sebagian kota Solo. Sedangkan wilayah Kasunanan meliputi daerah Kabupaten Sragen, Klaten, Boyolali, dan Kabupaten Kutha Surakarta.

Sukoharjo pada waktu itu hanya merupakan suatu daerah tepi dengan pimpinan pemerintahan tertinggi adalah "Wedono", tak ubahnya dengan Bekonang, dan Kartasura. Kawedanan Sukoharjo, Bekonang, dan Kartasura ini menjadi satu masuk wilayah Kabupaten Kutha Surakarta, di bawah pemerintah Kasunanan.
Pada tanggal 27 Mei 1946 Kabupaten Karanganyar secara defakto menyatakan diri lepas dari pemerintahan Mangkunegaran. Hal ini kemudian diikuti oleh Kabupaten Boyolali dan Sragen yang juga menyatakan diri lepas dari pemerintahan Kasunanan. Kabupaten Kutha Surakarta kemudian diputuskan pindah ke Sukoharjo. Bersamaan dengan munculnya gerakan anti Swapraja dan berbagai dukungan untuk membentuk pemerintah Kota Surakarta, akhirnya dengan suatu kebulatan tekad dari "Wong Solo", mereka menyatakan berdirinya Pemerintah kota Surakarta yang lepas dari Kasunanan pada tanggal 16 Juni 1946. Tanggal ini kemudian menjadi hari lahir Pemerintah Daerah Kotamadya Surakarta. Kemudian disusul keluarnya Penetapan Pemerintah Nomor: 16/SD tanggal 15 Juli 1946 lingkungan Karesidenan Surakarta dibentuk suatu daerah baru dengan kota Surakarta yang dikepalai oleh seorang Walikota.

Dengan keluarnya Penetapan Pemerintah Nomor: 16/SD tanggal 15 Juli 1946, maka secara formal Pemerintah Kasunanan dan Mangkunegaran dipandang sudah tidak ada lagi, dan wilayah-wilayahnya untuk sementara menjadi wilayah Karesidenan Surakarta. Ini berarti wilayah Karesidenan Surakarta terdiri dari bekas wilayah-wilayah Mangkunegaran yaitu Kabupaten Karanganyar dan Wonogiri, serta bekas wilayah Kasunanan yaitu Kabupaten Klaten, Sragen, Boyolali, dan Sukoharjo (Kawedanan Sukoharjo, Bekonang, Kartasura), ditambah Kotamadya Surakarta. Keadaan ini mengilhami para 
pemimpin pada waktu itu untuk membentuk kabupaten baru di luar kota Surakarta agar ketiga kawedanan (Sukoharjo, Bekonang, Kartasura) dapat dibina dalam satu naungan pemerintah kabupaten. Kemudian secara spontan KNI Daerah Surakarta menunjuk KRMT Soewarno Honggopati Tjitrohoepojo untuk menjadi Bupati. Atas dasar tersebut di atas serta pertimbangan analisa, logis dan kronologis yang dikaitkan dengan landasan yuridis meskipun landasan yuridis itu tidak bersifat mengatur secara khusus, maka pada hari Senin Pon tanggal 15 Juli 1946, saat ditetapkannya Penetapan Pemerintah Nomor: 16/SD tersebut ditetapkan menjadi Hari Lahir Kabupaten Sukoharjo. Penetapan ini kemudian dikukuhkan dengan Peraturan Daerah Kabupaten Dati II Sukoharjo No. 17 tahun 1986 tentang Hari Lahir Kabupaten Sukoharjo, yang disahkan dengan SK Gubernur KDH Tingkat I Jawa Tengah tanggal 15 Desember 1986 No. 188.3/480/1986 dan diundangkan dalam Lembaran Daerah Kabupaten Dati II Sukoharjo No. 3 Tahun 1987 Seri D No.2 tanggal 9 Januari 1987.

Dasar hukum Hari Lahir Sukoharjo adalah :

a. Penetapan Pemerintah Nomor: 16/SD.

b. Undang-Undang Nomor 13 Tahun 1950, tentang Pembentukan DaerahDaerah Kabupaten di wilayah Provinsi Jawa Tengah.

c. Peraturan Daerah Kabupaten Dati II Sukoharjo No. 17 tahun 1986 tentang Hari Lahir Kabupaten Sukoharjo, yang disahkan dengan SK Gubernur KDH Tingkat I Jawa Tengah tanggal 15 Desember 1986 No.188.3/480/1986 dan diundangkan dalam Lembaran Daerah Kabupaten Dati II Sukoharjo No. 3 Tahun 1987 Seri D No.2 tanggal 9 Januari 1987.

2. UMKM di Kabupaten Sukoharjo

UMKM di kabupaten Sukoharjo terdiri atas kluster-kluster seperti kluster rotan di Kecamatan Gatak, kluster gamelan di Wirun, Kecamatan Mojolaban, kluster jamu di Kecamatan Nguter dan sebagainya.

\section{B. Hasil Penelitian}

1. Praktik Akuntansi Laporan Keuangan UMKM di Kabupaten Sukoharjo

Dari hasil wawancara yang dilakukan peneliti kepada beberapa pelaku dari UMKM di Kabupaten Sukoharjo, secara umum masih banyak pelaku UMKM yang tidak melakukan pembukuan dan membuat laporan keuangan usahanya. Kebanyakan dari pelaku UMKM melakukan pencatatan yang berfungsi untuk mencatat kebutuhan apa saja yang usaha mereka perlukan, seperti barang-barang apa saja yang harus dibeli dan berapa harga pembelian barang tersebut. Nantinya informasi dari catatan tersebut digunakan oleh pemilik usaha mikro dalam menentukan berapa harga jual barangnya agar dapat untung. Ketika mereka ditanya mengapa tidak melakukan pembukuan dan membuat laporan keuangan, hampir semua pelaku UMKM mengungkapkan bahwa melakukan pembukuan dan membuat laporan keuangan tidak dapat mereka lakukan.

Sehingga dapat ditarik kesimpulan, bahwa mayoritas para pelaku UMKM di Kabupaten Sukoharjo tidak melakukan dan membuat laporan keuangan, karena keterbatasan pengetahuan tentang laporan 
keuangan serta minimnya peran serta pemerintah, khususnya pembinaan lewat kementerian koperasi dan UMKM yang tidak terlaksana.

2. Hambatan dalam Penerapan Akuntansi Laporan Keuangan

Berdasarkan pemaparan di atas dapat diketahui bahwa hambatan-hambatan yang dihadapi oleh pelaku Usaha Mikro Kecil dan Menengah dalam menerapkan Akuntansi Laporan Keuangan sebagai berikut: Pertama, ketidaktahuan tentang manfaat dari laporan keuangan bagi pengembangan usaha. Tidak sedikit pelaku UMKM yang belum mengetahui tentang manfaat dari penerapan akuntansi laporan keuangan bagi usahanya. Kedua, kurangnya pengetahuan pelaku Usaha Mikro Kecil dan Menengah dalam membuat laporan keuangan. Banyak pelaku UMKM yang tidak mengerti bagaimana untuk membuat laporan keuangan, mereka merasa kesulitan untuk membuat laporan keuangan. Ketiga, para pelaku UMKM belum merasakan secara langsung dari penerapan akuntansi laporan keuangan. Ada pelaku UMKM yang belum merasakan hasil dari kegiatannya menyusun laporan keuangan, sehingga mereka tidak lagi membuat laporan keuangan.Padahal dengan laporan keuangan pelaku UMKM dapat mengajukan kredit kepada lembaga keuangan untuk mengembangkan usahanya.

Hambatan dan kesulitan yang dihadapi usaha mikro dalam membuat laporan keuangan juga diungkapkan oleh Said (2009; Rudiantoro dan Siregar, 2011) bahwa banyak pemilik usaha mikro yang tidak membuat laporan keuangan karena keterbatasan pengetahuan pembukuan akuntansi, rumitnya proses akuntansi, dan anggapan bahwa laporan keuangan bukanlah hal yang penting bagi para pelaku UMKM di lapangan.

3. Cara Mengatasi Hambatan
Dalam mengatasi hamabatan-hambatan yang telah disebutkan di atas diperlukan peran serta dari pihak-pihak terkait untuk memberikan pemahaman kepada pelaku UMKM tentang pentingnya laporan keuangan bagi perkembangan usaha. Walaupun pemerintah maupun komunitas akuntansi (Lembaga profesi akuntan atau Ikatan Akuntan Indonesia/IAI) telah menegaskan pentingnya pencatatan dan penyelenggaraan informasi akuntansi bagi UMKM, dalam kenyataannya desakan hukum (law enforcement) atas praktik akuntansi pada UMKM dari regulator belum memadai (Pinasti, 2007), keberadaan SAK (sebelum diterbitkannya SAK ETAP) overload bagi UMKM (Wahdini \& Suhairi, 2006) dan belum efektifnya sosialisasi implementasi SAK ETAP terhadap pihak perbankan maupun lembaga UMKM (Rudiantoro \& Siregar, 2011). Hal ini menunjukkan bahwa untuk mengefektifkan praktik akuntansi pada UMKM, baik pemerintah, masyarakat maupun lembaga profesi akuntansi harus bersinergi dalam mendorong praktik akuntansi secara tepat, implementatif dan berkelanjutan.

Oleh karena itu, dalam rangka mengembangkan UMKM, sudah menjadi keharusan bagi seluruh pihak yang terkait untuk menciptakan UMKM yang mandiri, produktif dan berdaya saing tinggi. Sejalan dengan telah disalurkannya program kredit mudah dan murah oleh pemerintah, maka baik pemerintah, lembaga keuangan, lembaga profesi akuntansi maupun penyelenggara pendidikan harus dapat mendorong, membina dan memfasilitasi terselenggaranya praktik akuntansi secara tepat dan berkelanjutan pada UMKM khususnya di wilayahnya masing-masing. 
Namun, dibalik itu, para pelaku UMKM juga harus bisa merubah mindset atas praktik akuntansi. UMKM harus menunjukkan eksistensinya dan membangun kepercayaan pihak lembaga keuangan (bank dan non bank) melalui praktik akuntansi, sehingga UMKM dapat feasible, bankable, accountable, dan profitable serta dapat mengakses sumber daya produktif lainnya. Keterkaitan praktik akuntansi pada UMKM dengan akses UMKM terhadap sumber daya produktif, khususnya kredit UMKM serta peran serta pihak-pihak terkait dalam mendorong, membina dan memfasilitasi terselenggaranya praktik akuntansi secara tepat dan berkelanjutan dalam rangka mewujudkan UMKM yang mandiri, produktif dan berdaya saing tinggi. Sebagai upaya untuk meningkatkan kemampuan dan peran serta kelembagaan UMKM dalam perekonomian nasional, maka pemberdayaan tersebut perlu dilaksanakan oleh Pemerintah, Pemerintah Daerah, Dunia Usaha, dan masyarakat secara menyeluruh, sinergis, dan berkesinambungan. Sebagaimana diatur pada pasal 7 UndangUndang Republik Indonesia Nomor 20 Tahun 2008 Tentang Usaha Mikro, Kecil Dan Menengah, Pemerintah dan Pemerintah Daerah menumbuhkan Iklim Usaha dengan menetapkan peraturan perundang-undangan dan kebijakan yang meliputi aspek pendanaan, sarana dan prasarana, informasi usaha, kemitraan, perizinan usaha, kesempatan berusaha, promosi dagang, dan dukungan kelembagaan. Sedangkan dunia usaha dan masyarakat berperan serta secara aktif membantu upaya pemerintah dan pemerintah daerah dalam menumbuhkan iklim usaha tersebut.

\section{KESIMPULAN}

Dari analisis di atas, dapat diambil kesimpula, Pertama, penerapan laporan keuangan yang ada di Kabupaten Sukoharjo masih belum maksimal, banyak UMKM hanya menggunakan cacatan sederhana bahkan tidak membuat catatan keuangan sama sekali, sehingga menyebabkan belum optimalnya pemanfaatan informasi akuntansi dalam pengembangan UMKM. Kedua, hambatan yang dialami UMKM dalam menerapkan laporan keuangan adalah ketidaktahuan tentang manfaat dari laporan keuangan bagi pengembangan usaha, kurangnya pengetahuan pelaku Usaha Mikro Kecil dan Menengah dalam membuat laporan keuangan, pelaku UMKM belum merasakan secara langsung dari penerapan akuntansi laporan keuangan. Cara mengatasinya dibutuhkan peran pemerintah dan pihak-pihak yang terkait dalam membantu pelaku UMKM menerapkan laporan keuangan untuk memberdayakan usahanya. 


\section{DAFTAR PUSTAKA}

Amrin, Abdullah. 2009. Bisnis, Ekonomi, Asuransi, dan Keuangan Syariah. Jakarta: Gramedia Widiasarana Indonesia (Grasindo).

Arikunto, Suharsimi. 1998. Prosedur Penelitian Suatu Pendekatan Praktik. Jakarta: Rinika Cipta.

2006. Prosedur Penelitian Suatu Pendekatan Praktik. Jakarta: Rinika Cipta.

Baridwan. 2004. Intermediete Accounting. Yogyakarta: BPFE.

Direktorat Statistik Ekonomi dan Moneter Bank Indonesia. 2010. Metadata Kredit Usaha Mikro, Kecil dan Menengah (UMKM). http://www.bi.go.id/web/id/ Statistik/Metadata/SEKDA/.

Kementerian Negara Koperasi \& UKM RI. 2011. "Perkembangan Data Usaha Mikro, Kecil, Menengah (UMKM) Dan Usaha Besar (UB) Tahun 2006 - 2010".
Meigs, Walter B. and Robert F. Meigs.Financial Accounting, 4th ed. McGraw- Hill, 1970, p.1. ISBN 0-07-041534-X (old edition).

Presiden Republik Indonesia. 2008. "UndangUndang Republik Indonesia Nomor 20 Tahun 2008 Tentang Usaha Mikro, Kecil Dan Menengah".

Rodhiyah. 2012. "Kajian Tentang Akuntabilitas Usaha Kecil Menengah Melalui Laporan Keuangan”. Semarang: UNDIP.

Rudiantoro, Rizki \& Siregar, Sylvia Veronica. 2012. "Kualitas Laporan Keuangan Umkm Serta Prospek Implementasi Sak Etap". Jakarta : Universitas Indonesia.

Sugiono, Arief dan Untung Edy. 2008. Panduan Praktis Dasar Analisa Laporan Keuangan. Jakarta: Gramedia Widiasarana Indonesia (Grasindo). 